\title{
FISCAL EFFECTS OF LOCAL OPTION SALES TAX ON SCHOOL FACILITIES FUNDING: EVIDENCE FROM NORTH CAROLINA
}

\author{
Wen Wang \\ Department of Public and Social Administration \\ City University of Hong Kong \\ Tat Chee Avenue, Kowloon, Hong Kong \\ (852) 3442-8273 \\ wenwang@gmail.com \\ Zhirong (Jerry) Zhao \\ Hubert H. Humphrey Institute of Public Affairs \\ University of Minnesota \\ \#246 Humphrey Center \\ $301,19^{\text {th }}$ Avenue South \\ Minneapolis, MN 55455 \\ 612-625-7318 \\ zrzhao@umn.edu
}

Wang, W., \& Zhao, Z. J. (2010). Fiscal Effects of Local Option Sales Tax on School Facilities Funding: Evidence from North Carolina. http://dx.doi.org/10.2139/ssrn.1669931 


\title{
FISCAL EFFECTS OF LOCAL OPTION SALES TAXES ON SCHOOL FACILITIES FUNDING: THE CASE OF NORTH CAROLINA
}

\begin{abstract}
Since the 1970s, the North Carolina Legislature has authorized its counties to levy four local option sales taxes (LOST). Proceeds from two of them are partially restricted for school capital needs; two other LOST are used to augment counties' general revenues that may also affect school capital funding. Experiences from other states have raised concerns that the adoption of LOST may increase inequality in school finance, but the empirical results have been mixed. Using a data set of one hundred North Carolina county school districts from 2004 to 2006 , this study examines how public school facilities are funded, and investigates whether the adoption of LOST aggravates or alleviates inequality in public school capital revenues in the state.
\end{abstract}




\section{INTRODUCTION}

Public school enrollment in North Carolina (NC) has increased rapidly since the 1990s (Gerald and Hussar, 2003), and the trend of growth is expected to continue (SBE, 2006). Ninety percent of schools in NC reported a need to upgrade or repair their buildings to good overall condition (GAO, 1996). The Facility Needs Survey identified total school facility needs of $\$ 9.8$ billion in $\mathrm{NC}$ over a five-year period (SBE, 2006). The court order in a recent lawsuit, known as Leandro, ${ }^{\mathrm{i}}$ has led many $\mathrm{NC}$ districts to increase their spending on new classrooms for at-risk students in kindergarten. Overall, the growing need for school facilities, the challenges in state courts, and the implementation of class size reduction programs have pressured the state and its local governments not only to increase their level of spending for public school facilities, but also to improve the equity of public school capital outlays.

In $\mathrm{NC}$, school facilities have been funded mainly by local governments through general revenue allocation or issuing general obligation (GO) bonds (NCES, 2001). Nevertheless, the debt limitation imposed by the state, ${ }^{\text {ii }}$ the tight oversight of the Local Government Commission (Coe, 2007), and the requirement of voter approval for debt issuance have limited the amount of capital revenue school districts can generate. In recent decades, the state has provided state aid programs or new means to supplement local revenues for financing school facilities. In particular, the NC Legislature has authorized its counties to levy four local option sales taxes (LOST) since the 1970s. Proceeds from two one-half-cent LOST (in 1983 and 1986, respectively) are partially earmarked for school capital outlays or for debt service on county borrowing for school projects (NCES, 2001; Lawrence and Millonzi, 2007). In addition, the state legislature 
authorized two other LOST that are used as counties' general revenues, which may also affect school capital funding, albeit indirectly.

Earmarking sales tax revenue for education is a recent development, although local sales taxes have a long history in the U.S. Georgia is one of the few states to earmark LOST for education, specifically for the construction of school facilities and retirement of debt (Rubenstein and Freeman, 2003). School districts in South Carolina also were authorized to impose LOST for specific education capital improvement, although no district there has adopted the tax. Experiences from other states have raised concerns that the adoption of LOST may increase inequality in school finance, since the unevenly distributed sales tax proceeds may exacerbate existing inequality in property tax revenues that often serve as the primary local source for school districts. The empirical results, however, have been mixed (Rubenstein and Freeman, 2003; Zhao and Hou, 2008).

Using a data set of one hundred counties from 2004 to 2006, this study examines whether the LOST aggravate or alleviate inequality in public school capital revenue in NC. We ask three research questions: (1) How are public school capital revenues and the LOST proceeds distributed across counties in NC? (2) How did various revenue sources, in particular the LOST proceeds, contribute to the dispersion of public school capital revenue in recent years? (3) How would the equity impact change if the LOST proceeds are earmarked at different levels or allocated in different ways? The results of the study will shed light on the policy design and fiscal impacts of using LOST for financing public schools, which has been more widely adopted or considered in some states in recent years. 
This paper is divided into six sections. Following the introduction, the second section describes how public school capital outlays are funded by state and local revenues in NC. The third section briefly reviews literature on school facilities funding in the U.S. and fiscal effects of LOST. The fourth section discusses research questions, data, and research methodology. The fifth section analyzes the disparities in funding for public school facilities, and examines the equity impact of LOST on public school capital revenues, both in the current situation and in alternative scenarios of LOST earmarking and allocation. The final section concludes and discusses directions for future research.

\section{SCHOOL FACILITIES FUNDING IN NORTH CAROLINA}

School districts in NC, including one hundred county units and fifteen city units, are fiscally dependent on the counties and the state government (Mesibov and Johansen, 2007). Since the 1930s, NC has established a basic structure of school finance with a division of responsibility between state and county. The state is mainly responsible for current expenses necessary to maintain the minimum nine-month term, while counties are mainly responsible for financing construction and maintenance of school facilities. However, over time, the state has frequently supplemented funds for school construction, and counties have also provided funds to supplement state funding for school current expenditures (Mesibov and Johansen, 2007).

Local funds for school capital outlays may come from three sources (G.S. 115C$42 \mathrm{~b}(\mathrm{f}))$. First, through the regular budget process, counties may appropriate part of their general revenues for school capital projects. Second, voters within a school unit may approve by referendum a levy of supplemental property tax for school expenditures. 
Finally, counties may raise money for school construction through by issuing GO bonds (Lawrence and Vogt, 2007).

Table 1: LOST and State Aid Programs for Public School Facilities in NC

\begin{tabular}{|c|c|c|c|}
\hline & Authorization & Distribution & Earmarking \\
\hline Earmarked LOST & 1983 & Per capita basis & $\begin{array}{c}40 \% \text { in the first 5 years, and } \\
30 \% \text { in the next 23 years }\end{array}$ \\
\hline Article 40 & 1986 & Per capita basis & $60 \%$ in the first 25 years \\
\hline Article 42 & 1971 & Point-of-sale & \\
\hline Un-earmarked LOST & $\begin{array}{c}\text { Half point-of-sale, half } \\
\text { on per capita basis }\end{array}$ & \\
\hline Article 39 & 2002 & $\begin{array}{c}\text { Average Daily } \\
\text { Article 44 }\end{array}$ & $\begin{array}{c}\text { ADMership (ADM) } \\
\text { pay (35\%), growth (25\%) }\end{array}$ \\
\hline State Aid Revenues & 1987 \\
$\begin{array}{c}\text { School Building } \\
\text { Capital Fund }\end{array}$ & 1996 \\
$\begin{array}{c}\text { School Building } \\
\text { Bond Fund }\end{array}$ & \multicolumn{3}{|l|}{} \\
\hline
\end{tabular}

Over the years, the state has offered direct and indirect assistance for school construction. One kind of state assistance has been the authorization of LOST. As indicated in Table 1, in 1983, the state legislature authorized counties to levy an additional one-half-cent LOST (Article 40 tax), with the proceeds partially earmarked for school capital outlay or retirement of existing school indebtedness. In the first five fiscal years after the tax was imposed, the counties were required to use 40 percent of the proceeds for school capital outlay or retirement of indebtedness related to capital outlays; in the next twenty-three fiscal years, they were to use 30 percent for those purposes. In 1986, the state legislature authorized another half-cent LOST (Article 42 tax). In the first twenty-five years of the tax, counties were required to use 60 percent of the proceeds for public school capital outlay or to repay school debt incurred during the five years before the tax became effective. The two LOST are collected by the state together with state sales tax. After subtracting administrative costs, the proceeds are placed in a statewide 
pool and allocated among the one hundred counties on a per capita basis. With these features, the two local sales taxes are often viewed as a form of state revenue sharing because, in fact, the state is collecting a traditional state revenue source, i.e. retail sales tax, and giving it to local units for school facilities (Mesibov and Johansen, 2007). Another type of state assistance for school construction has been state aid programs. In 1987, NC increased its corporate income tax from 6 to 7 percent and established the Public School Building Capital Fund to provide additional state monies for school construction. ${ }^{\text {iii }}$ Allocated according to school enrollments, the Public School Building Capital Fund provides aid to all school districts for school building capital needs or school technology needs (SBE, 2005). Funds for capital projects must be matched by $\$ 1$ of local funds for each $\$ 3$ of state funds; earmarked local sales tax revenues can be used as local matching funds. In 1996, the state enacted the Public School Building Bond Act, which authorized the issuance of up to $\$ 1.8$ billion in state GO bonds for school capital outlay purposes. For this program, 40 percent of the aid is allocated based on the unit's average daily membership (ADM), 35 percent on its ability-to-pay, and 25 percent on the unit's growth. These funds have local matching requirements except the part allocated based on the ability-to-pay (SBE, 2005).

From 1984 to 1993, the two earmarked LOST and the two state aid funds provided local units nearly $\$ 1.5$ billion in additional funds for school construction. However, the amount represented only about half of the $\$ 3$ billion spent on school construction during this period. Counties provided the other half through local revenue sources and debt financing. In recent years, debt financing has become increasingly popular and accounted for a larger share of total capital revenue, partly because one 
effective way for a county to take advantage of state aid is to leverage it by issuing bonds, which are then paid back through earmarked sales tax revenues (Mesibov and Johansen, 2007).

To summarize, public school facilities in NC is funded by (1) county effort, mostly general fund allocation and GO bonds, and (2) state provisions, including partially earmarked LOST and state aid programs. The focus of this study is how the adoption of LOST, in conjunction with other capital revenues, may contribute to inequality of school facilities funding. For this purpose, we would like to note two additional NC LOST that are not earmarked for school facilities but are nonetheless involved in this analysis. These two are Article 39 one-cent LOST and Article 44 half-cent LOST, authorized in 1971 and 2002, respectively. Proceeds of the Article 39 tax are returned to the county to which the goods were sold. Proceeds of the Article 44 tax are divided in half; one half is allocated on a per capita basis, and the other half is returned to the county in which the goods were delivered (Lawrence and Millonzi, 2007). Although these LOST are used as counties' general revenues, they may have indirect effects on school capital funding, because county general support is an important source of school capital outlays in NC.

\section{PREVIOUS LITERATURE}

Recent years have seen a growing interest in the way state and local governments finance their school infrastructure. Besides general concerns over the level of spending on school facilities, there has also been a concern about the distribution of the capital spending (and facility condition) across school districts (Brunner and Rueben, 2001). The constitutionality of school finance systems has been increasingly challenged in many 
states because of inequities in school facilities across school districts (Brunner and Rueben, 2001; Gamkhar and Koerner, 2002; Plummer, 2006). In NC, school districts have effectively used evidence of deficient school facilities as part-and-parcel of a comprehensive attack on the state's school finance scheme (Sciarra, Bell and Kenyon, 2006). iv

In many states, local revenues for school infrastructure mainly are raised from voter-approved GO bond issues, which are typically paid back by temporary property tax increases. Reliance on local property taxes to finance school infrastructure has raised concerns about the equity of school facility finance in many states. For example, in 1994 the Arizona Supreme Court ruled the reliance on local GO bonds to finance school facilities unconstitutional. In response, Arizona state government took over the responsibility of financing school facilities from local school districts (Brunner and Rueben, 2001). Studies such as Wang (2004) and Wang and Duncombe (2009) provide descriptive information on state funding mechanisms for school infrastructure.

However, few studies in the literature have examined the inequality of school capital outlays, probably because related equity concerns and reform measures have occurred fairly recently (Plummer, 2006). Brunner and Rueben (2001) study the level and distribution of school facility spending for California from 1992 through 1999. They find large disparities in the distribution of capital revenues across school districts. Those with higher property values have significantly higher capital revenue, raising concerns about the equity of school facility funding in California. ${ }^{\mathrm{v}}$ Likewise, Burton (1999) finds that disparities exist between school facilities where poor and non-poor are educated in NC. The condition of school facilities worsens as the share of low-income students increases. ${ }^{\text {vi }}$ 
As this study does not control for the impact of factors other than income level and racial composition of students on the condition of school facilities, their relationship with the condition of school facilities in NC still needs further investigation. Plummer (2006) studies the equity effects of two Texas state programs, the Existing Debt Allotment (EDA) program and the Instructional Facilities Allotment (IFA) program. The results show that EDA has not provided significant property tax relief, as intended, for districts receiving its funds, and IFA has not been effective in achieving greater capital outlay equity across districts at different wealth levels.

There are few journal articles related to LOST and fiscal disparity. Rubenstein and Freeman (2003) report that property tax has remained the dominant revenue source for school funding over the years. They conclude that the differences in sales tax bases across school districts in Georgia may have exacerbated the existing fiscal inequities among school districts, which mainly relies on local property tax as the primary revenue source. The main reason for this phenomenon is that sales tax base tends to concentrate in heavily populated urban and suburban areas, and that the state does little in its funding formulas to equalize differences in sales tax capacity or property tax wealth. Later, Zhao and Hou (2008) examine the effects of LOST on fiscal disparities across counties in Georgia, and find more complicated results. Using Georgia county data from 1970-2000, their analysis shows that the effects of LOST are sensitive to whether the RepresentativeTax-System (RTS) or the Income-With-Exporting (IWE) approach is used to measure revenue-raising capacity of local governments. ${ }^{\text {vii }}$ Based on the IWE approach, the analysis shows that introducing LOST does exacerbate revenue disparity associated with the property tax across counties in Georgia. Analysis based on the RTS approach, 
however, indicates that the addition of LOST may alleviate fiscal inequality, because the two revenue sources, i.e. property tax and LOST, are distributed in somewhat offsetting patterns.

\section{RESEARCH QUESTIONS, DATA, AND METHODOLOGY}

The objective of this study is to examine whether the adoption and restricted use of the two earmarked LOST exacerbate or alleviate the inequality in public school capital revenue in NC. Other than the two LOST, NC school districts also rely heavily on local property tax levies and state aid programs for capital outlays. Local property tax levies are commonly assumed to be the major factor of education fiscal disparity (Rubenstein and Freeman, 2003), while the two state aid programs are expected to have some equalizing effects. The possible effects of LOST on education finance equity hinge not (1) whether the proceeds are unevenly distributed, and (2) how the distribution of LOST proceeds relate to the distribution of other revenues (Zhao and Hou, 2008).

Moreover, the NC case has two additional features adding to the complexity of LOST's equalizing effect. First, because restricted proceeds from Article 40 and 42 taxes are placed in a statewide pool and then allocated on a per capita basis instead of a pointof-sale basis, they may have equalizing effects on school finance to the extent that the population size positively correlates with total pupil numbers. Second, the unrestricted portion of LOST proceeds - including un-earmarked parts of Article 40 and 42 taxes, and all of Article 39 and 44 taxes - are added to county general funds before partial allocation for education including school capital expenditures. As additional revenue sources, these LOST proceeds will change the distribution of county fiscal capacity and 
then indirectly affect distribution of school capital outlays. Consequently, it would be interesting to separate the equalization effects of restricted and unrestricted portions of LOST proceeds as they interplay with other revenue sources in the overall dispersion of school capital outlays. Moreover, the earmarked ratio of LOST for school capital outlays has changed over time, and the proceeds may be allocated in different ways (for instance, per pupil instead of per capita). We will also examine the equity effect for alternative scenarios of LOST earmarking and allocation, which bear direct implications for policy designs about LOST.

As mentioned above, the key research questions include (1) the distribution of LOST proceeds in related to other school capital revenues, (2) the equity effect of LOST proceeds in school capital revenues, and (3) the equity effect of LOST proceeds in alternative scenarios of policy design. For this study, we assembled a data set of one hundred counties in NC for the period of 2004-2006, based on financial data provided by the NC Department of State Treasurer (2010) and socioeconomic data provided by the U.S. Census Bureau (2010). ${ }^{\text {viii }}$ To address the first research question, we will use standard descriptive statistics to analyze LOST and total public school capital revenues among counties in NC. To answer the second and third questions, we will measure fiscal inequalities with the Gini index (Gini, 1912), ${ }^{\mathrm{ix}}$ and then we employ the standard decomposition of the Gini coefficient to examine the contribution of multiple revenue sources - in particular, earmarked and unrestricted LOST proceeds - to the dispersion of total school capital revenue. With this method, we can decompose the Gini index of a total revenue as multiple pseudo-Gini indices that account for each single revenue source, calculate the absolute and relative contribution of each revenue source to the total 
revenue inequality (Fei, Ranis, and Kuo, 1978), and then estimate the marginal effect of each revenue source on the inequality of total revenue (Lerman and Yitzhaki, 1985). For technical notes of the standard Gini decomposition, see the Appendix.

\section{EMPIRICAL ANALYSIS}

\section{The Distribution of LOST and Other Capital Revenues}

Table 2 reports the distribution of per pupil public school capital revenues by sources in $2006 .{ }^{\mathrm{x}}$ North Carolina counties, on average, raised $\$ 450.7$ per pupil for school facilities, with restricted LOST proceeds covering $\$ 132$, or around 30 percent, of the total revenue in 2006. A typical county may issue GO bonds only once in a period of several years and spread out the use of bond proceeds in multiple years. Therefore, in this study, we average the newly issued debt amounts for each county in a nine-year period (19982006), about one-third of typical maturity term for GO bonds, to account for the average level of debt use. ${ }^{\mathrm{xi}}$ Newly issued debt proceeds amounted to $\$ 188$, or about 40 percent, of the total capital revenue, while state aid only funded 5 percent of public school capital revenue. County general support represents a county's contribution to public school capital revenues from county general funds that come from property tax, unrestricted LOST, and other sources. ${ }^{\mathrm{xii}}$ It funded about one-fourth of the total school capital revenue in 2006 . 
Table 2: Per Pupil School Capital Revenue by Sources (2006)

\begin{tabular}{|l|r|r|r|r|r|}
\hline & Mean & St.D. & Min & Median & Max \\
\hline Restricted LOST proceeds & 132.0 & 32.8 & 71.7 & 126.2 & 252.2 \\
\hline From LOST-Article 40 & 44.4 & 16.4 & 0.0 & 42.2 & 165.0 \\
\hline From LOST-Article 42 & 86.1 & 19.8 & 47.7 & 83.4 & 156.9 \\
\hline State aid revenues & 23.1 & 29.5 & 0.0 & 19.0 & 162.0 \\
\hline From School Building Capital Fund & 21.0 & 26.5 & 0.0 & 17.5 & 162.0 \\
\hline From School Building Bond Fund & 2.2 & 15.9 & 0.0 & 0.0 & 153.6 \\
\hline County general support & 107.6 & 164.0 & 0.0 & 45.8 & 910.9 \\
\hline From property tax & 42.0 & 65.1 & 0.0 & 15.0 & 378.0 \\
\hline From unrestricted LOST proceeds & 12.6 & 18.5 & 0.0 & 5.3 & 100.8 \\
\hline From other revenue sources & 53.1 & 86.4 & 0.0 & 21.3 & 610.3 \\
\hline Debt proceeds for school facilities & 188.0 & 202.6 & 0.0 & 137.8 & 1216.6 \\
\hline Total school capital revenue & $\mathbf{4 5 0 . 7}$ & $\mathbf{4 2 9 . 0}$ & $\mathbf{7 1 . 7}$ & $\mathbf{3 2 8 . 8}$ & $\mathbf{2 5 4 1 . 8}$ \\
\hline
\end{tabular}

Table 3 presents the three-year average of capital revenue sources in the period of 2004-2006 by quartiles for NC counties based on per pupil total capital revenue. While counties in the first quartile can raise, on average, $\$ 151.9$ per pupil for their public school capital projects, those in the fourth quartile can only raise $\$ 1047.3$ per pupil. The coefficient of variation for the three-year average per pupil total capital revenue is 0.75 , and the Gini coefficient is 0.38 for all counties in the period of 2004-2006. This indicates substantial disparities in the capacity of counties to raise funds for public school capital outlays. In the table we see that, in general, total capital revenue is positively associated with county general support, earmarked LOST revenue, and state aid support. For instance, state aid from the School Building Capital Fund for counties in the upper three quartiles appears to be significantly higher than that in the first quartile. The table also suggests that counties with higher per pupil total capital revenue tend to rely more on GO bonds to finance school capital spending. 
Table 3: Revenue Sources By Quartiles of Total Capital Revenue Per Pupil (2004-2006)

\begin{tabular}{|c|c|c|c|c|c|}
\hline & $\begin{array}{c}1 \mathrm{st} \\
\text { Quartile }\end{array}$ & $\begin{array}{c}\text { 2nd } \\
\text { Quartile }\end{array}$ & $\begin{array}{c}\text { 3rd } \\
\text { Quartile }\end{array}$ & $\begin{array}{c}\text { 4th } \\
\text { Quartile }\end{array}$ & Total \\
\hline & $(n=25)$ & $(n=25)$ & $(\mathrm{n}=25)$ & $(n=25)$ & $(\mathrm{n}=100)$ \\
\hline \multicolumn{6}{|l|}{ Per-pupil education capital revenue } \\
\hline Earmarked LOST proceeds & 116.9 & 124.5 & 138.8 & 117.7 & 124.5 \\
\hline Total state aid & 9.8 & 30.5 & 27.8 & 26.3 & 23.6 \\
\hline School Building Capital Fund & 6.6 & 23.5 & 24.9 & 20.5 & 18.9 \\
\hline School Building Bond Fund & 3.2 & 6.9 & 2.9 & 5.8 & 4.7 \\
\hline County general support & 9.1 & 49.1 & 107.5 & 255.4 & 105.2 \\
\hline Newly issued GO bonds & 6.2 & 31.6 & 175.0 & 621.6 & 208.6 \\
\hline Total & 151.9 & 266.0 & 476.8 & 1047.3 & 485.5 \\
\hline Net debt proceeds per-pupil & -31.3 & -74.2 & 1.3 & 345.1 & 60.2 \\
\hline \multicolumn{6}{|l|}{ Fiscal capacity of NC counties } \\
\hline Property tax base per pupil $(\$ 1000)$ & 186.6 & 227.3 & 294.9 & 330.1 & 259.7 \\
\hline County property tax rate & $0.65 \%$ & $0.57 \%$ & $0.56 \%$ & $0.56 \%$ & $0.59 \%$ \\
\hline Total LOST proceeds per-pupil & 548.6 & 582.7 & 702.5 & 701.2 & 633.8 \\
\hline \multicolumn{6}{|l|}{ Student characteristics } \\
\hline Average enrollment & 9,495 & 8,957 & 9,292 & 26,642 & 13,597 \\
\hline Enrollment growth (2004-2006) & $-0.64 \%$ & $1.50 \%$ & $0.32 \%$ & $4.29 \%$ & $2.11 \%$ \\
\hline Percent of African American students & $36.29 \%$ & $28.87 \%$ & $27.01 \%$ & $24.12 \%$ & $29.07 \%$ \\
\hline Percent of minority students & $46.68 \%$ & $36.31 \%$ & $34.30 \%$ & $34.00 \%$ & $37.82 \%$ \\
\hline Percent of children in poverty & $24.59 \%$ & $19.67 \%$ & $20.49 \%$ & $16.50 \%$ & $20.31 \%$ \\
\hline
\end{tabular}

The distribution of debt proceeds is worth our special attention, since it amounts to around 40 percent of the total school capital revenue. In Table 3 we also present "net debt proceeds" per pupil calculated by subtracting debt service payments from the proceeds of newly issued debt. The negative amount of "net debt proceeds" for counties in the first two quartiles indicates that these counties had higher debt service payments than the amount of debt newly issued. This might happen due to a combined reason that (1) these counties have exhausted their debt capacity with high level of outstanding debt, and (2) they may be facing higher borrowing costs because of lower levels of fiscal capacity. The significantly higher amounts of both newly issued debt and net debt in 
counties of the top quartile appear to be the major factor driving the difference in school capital revenues between these counties and the others in the state. .iii $^{\text {ii }}$

In terms of fiscal capacity, counties with higher per pupil school capital revenues appear to have higher per pupil property tax base and total LOST revenue. Regarding student characteristics, higher capital-spending schools have much larger average enrollment and higher enrollment growth, lower shares of children aged 5-17 in families in poverty, ${ }^{\text {xiv }}$ and lower property tax rates. These results suggest that revenue for public school capital outlays is positively associated with the fiscal capacity of counties. Districts with a higher share of disadvantaged students (including African American and minority students) and children in families in poverty, have less revenue available for their public school infrastructure.

Table 4 shows the capital revenue sources by quartiles of per pupil total LOST proceeds that were received by NC counties. First, per pupil total LOST proceeds have a strong positive correlation with per pupil property tax base and county general support, but they are negatively related to property tax rates, proportions of African American and minority students, and children in families in poverty. This indicates that the adoption and use of LOST disproportionately benefits counties with higher source revenue capacity, those that were wealthier, and those that allocated more for school capital outlays despite lower level of tax efforts. Second, most counties with less LOST proceeds appear to receive slightly higher amounts of total state aid per pupil. 
Table 4: Revenue Sources By Quartiles of Total LOST Proceeds Per Pupil (2004-2006)

\begin{tabular}{|l|c|c|c|c|c|}
\hline & $\begin{array}{c}1 \text { st } \\
\text { Quartile } \\
(\mathrm{n}=25)\end{array}$ & $\begin{array}{c}\text { 2nd } \\
\text { Quartile } \\
(\mathrm{n}=25)\end{array}$ & $\begin{array}{c}\text { 3rd } \\
\text { Quartile } \\
(\mathrm{n}=25)\end{array}$ & $\begin{array}{c}\text { 4th } \\
\text { Quartile } \\
(\mathrm{n}=25)\end{array}$ & $\begin{array}{c}\text { Total } \\
(\mathrm{n}=100)\end{array}$ \\
\hline Per-pupil education capital revenue \\
\hline Earmarked LOST proceeds & 110.1 & 112.5 & 127.7 & 147.7 & 124.5 \\
\hline Total state aid & 25.8 & 23.7 & 22.7 & 22.2 & 23.6 \\
\hline School Building Capital Fund & 17.0 & 18.7 & 19.3 & 20.6 & 18.9 \\
\hline School Building Bond Fund & 8.8 & 5.0 & 3.4 & 1.6 & 4.7 \\
\hline County general support & 67.5 & 83.5 & 92.5 & 177.4 & 105.2 \\
\hline Newly issued GO bonds & 127.8 & 212.0 & 199.0 & 295.6 & 208.6 \\
\hline Total & 356.9 & 455.4 & 464.6 & 665.1 & 485.5 \\
\hline \multicolumn{7}{|l|}{} & & & \\
\hline Net debt proceeds per-pupil & 27.4 & 89.5 & 36.2 & 87.8 & 60.2 \\
\hline Fiscal capacity of NC counties & 168.8 & 189.3 & 237.8 & 442.8 & 259.7 \\
\hline Property tax base per pupil (\$1000) & $0.63 \%$ & $0.66 \%$ & $0.61 \%$ & $0.45 \%$ & $0.59 \%$ \\
\hline County property tax rate & 469.7 & 535.2 & 622.8 & 907.3 & 633.8 \\
\hline Total LOST proceeds per-pupil & \multicolumn{5}{|l|}{} \\
\hline Student characteristics & 12,688 & 16,909 & 12,768 & 12,021 & 13,597 \\
\hline Average enrollment & $2.26 \%$ & $1.75 \%$ & $1.88 \%$ & $2.53 \%$ & $2.11 \%$ \\
\hline Enrollment growth (2004-2006) & $35.65 \%$ & $35.08 \%$ & $34.03 \%$ & $11.51 \%$ & $29.07 \%$ \\
\hline Percent of African American students & $46.96 \%$ & $43.75 \%$ & $41.68 \%$ & $18.89 \%$ & $37.82 \%$ \\
\hline Percent of minority students & $21.36 \%$ & $20.53 \%$ & $20.24 \%$ & $19.13 \%$ & $20.31 \%$ \\
\hline Percent of children in poverty
\end{tabular}

Interestingly, the pattern of distribution was different for two state aid funds.

Counties with less LOST proceeds actually got less from School Building Capital Fund, probably because the Fund requires $1 / 3$ matching of local funds, for which earmarked LOST proceeds may be used. ${ }^{\mathrm{xv}}$ In contrast, counties with less LOST proceeds received more support from School Building Bond Fund, because the Fund distributes 35 percent of its revenues negatively related to counties' ability-to-pay, which is ranked in line with both property tax base and the amount of LOST proceeds. 


\section{LOST and School Capital Revenue Inequalities}

In Table 5, we present Gini indices for total school capital revenue as well as the impact of various revenue sources on capital revenue disparities during 2004-2006. ${ }^{\mathrm{xvi}}$ Following the methods discussed in the previous section, we decompose the Gini index to show the contribution of multiple revenue sources—in particular, restricted and unrestricted LOST proceeds - to the dispersion of total school capital revenue.

Table 5 reports that the Gini index of per pupil total school capital revenue varied between 0.37 and 0.39 in 2004-2006. The first panel in the table shows the Pseudo-Ratio of each revenue source. ${ }^{\text {xvii }}$ The ratio is calculated as the Pseudo-Gini of a revenue source divided by the Gini index of total capital revenue. A larger-than-1 Pseudo-Ratio indicates that a revenue source is more widely dispersed along the rank of the total revenue and, thus, is a driving force of the overall inequality. Total county general support has the highest level of Pseudo-Ratio, at or above 1.60 during 2004-2006. This echoes the expectation that unevenly distributed local government fiscal capacity (in particular, property tax base) tends to drive up disparity in education finance. In addition, the ratio of 1.38 for new debt proceeds (a nine-year average amount) indicates that this particular revenue source is over-dispersed than the total revenue. This can be in part explained by the fact that debt issuance is infrequent and disparate. In fact, nineteen counties did not issue debt for school infrastructure during 1998-2006, while the twenty-five counties with the highest levels of school capital revenues on average issued over $\$ 600$ per pupil annually, which accounted for over half of their total school capital revenue (see Table 3). 
Table 5: Standard Decomposition of Gini Coefficient by Revenue Sources

\begin{tabular}{|c|c|c|c|}
\hline & 2004 & 2005 & 2006 \\
\hline Gini index of total school capital revenue: & 0.37 & 0.39 & 0.37 \\
\hline \multicolumn{4}{|c|}{ Pseudo-Gini/Gini of total school capital revenue: } \\
\hline Restricted LOST proceeds & 0.02 & 0.03 & 0.01 \\
\hline From LOST-Article 40 & 0.05 & 0.05 & 0.00 \\
\hline From LOST-Article 42 & 0.01 & 0.02 & 0.01 \\
\hline State aid revenues & 0.61 & 0.31 & 0.62 \\
\hline From School Building Capital Fund & 0.82 & 0.37 & 0.62 \\
\hline From School Building Bond Fund & 0.08 & 0.09 & 0.63 \\
\hline County general support & 1.60 & 1.60 & 1.64 \\
\hline From property tax & 1.62 & 1.59 & 1.63 \\
\hline From unrestricted LOST proceeds & 1.54 & 1.54 & 1.58 \\
\hline From other revenue sources & 1.61 & 1.62 & 1.67 \\
\hline Debt proceeds for school facilities & 1.38 & 1.34 & 1.38 \\
\hline Total school capital revenue & 1.00 & 1.00 & 1.00 \\
\hline \multicolumn{4}{|c|}{ Relative contribution to Gini of total school capital revenue: } \\
\hline Restricted LOST proceeds & $0.5 \%$ & $0.8 \%$ & $0.1 \%$ \\
\hline From LOST-Article 40 & $0.4 \%$ & $0.5 \%$ & $0.0 \%$ \\
\hline From LOST-Article 42 & $0.1 \%$ & $0.4 \%$ & $0.2 \%$ \\
\hline State aid revenues & $4.1 \%$ & $1.3 \%$ & $3.2 \%$ \\
\hline From School Building Capital Fund & $4.0 \%$ & $1.3 \%$ & $2.9 \%$ \\
\hline From School Building Bond Fund & $0.1 \%$ & $0.1 \%$ & $0.3 \%$ \\
\hline County general support & $36.1 \%$ & $39.9 \%$ & $39.2 \%$ \\
\hline From property tax & $14.8 \%$ & $15.7 \%$ & $15.2 \%$ \\
\hline From unrestricted LOST proceeds & $4.3 \%$ & $4.9 \%$ & $4.4 \%$ \\
\hline From other revenue sources & $17.1 \%$ & $19.4 \%$ & $19.7 \%$ \\
\hline Debt proceeds for school facilities & $59.2 \%$ & $57.9 \%$ & $57.4 \%$ \\
\hline Total school capital revenue & $100.0 \%$ & $100.0 \%$ & $100.0 \%$ \\
\hline \multicolumn{4}{|c|}{ Marginal effects to Gini of total school capital revenue: } \\
\hline Restricted LOST proceeds & $-27.2 \%$ & $-26.8 \%$ & $-29.1 \%$ \\
\hline From LOST-Article 40 & $-9.0 \%$ & $-9.0 \%$ & $-9.8 \%$ \\
\hline From LOST-Article 42 & $-18.1 \%$ & $-17.5 \%$ & $-18.9 \%$ \\
\hline State aid revenues & $-2.6 \%$ & $-2.9 \%$ & $-2.0 \%$ \\
\hline From School Building Capital Fund & $-0.8 \%$ & $-2.1 \%$ & $-1.8 \%$ \\
\hline From School Building Bond Fund & $-1.7 \%$ & $-0.8 \%$ & $-0.2 \%$ \\
\hline County general support & $13.6 \%$ & $14.9 \%$ & $15.4 \%$ \\
\hline From property tax & $5.6 \%$ & $5.8 \%$ & $5.8 \%$ \\
\hline From unrestricted LOST proceeds & $1.5 \%$ & $1.7 \%$ & $1.6 \%$ \\
\hline From other revenue sources & $6.4 \%$ & $7.4 \%$ & $7.9 \%$ \\
\hline Debt proceeds for school facilities & $16.2 \%$ & $14.8 \%$ & $15.7 \%$ \\
\hline Total school capital revenue & $0.0 \%$ & $0.0 \%$ & $0.0 \%$ \\
\hline
\end{tabular}


In contrast, a positive and smaller-than-1 Pseudo-Ratio indicates that a revenue source is less widely dispersed along the rank of the total revenue and thus is modifying the overall inequality; a negative Pseudo-Ratio will mean that a revenue source is negatively dispersed along the rank of the total revenue and, thus, has a strong equalization effect. With the Pseudo-Ratio, we may distinguish two kinds of equalization effects: a strong equalization effect (“offsetting”) indicated by a negative Pseudo-Ratio, and a weak equalization effect ("pooling") indicated by a positive yet smaller-than-1 Pseudo-Ratio (Zhao, 2009). The ratio of 0.62 for total state aid in 2006, for instance, signifies the "pooling" equalization effect of the revenue source. We do not see any “offsetting" equalization effect of various revenue sources over the period of 2004-2006. Regarding the focus of this study - the effects of LOST proceeds - we find that the ratio is around $0.01-0.03$ for restricted LOST proceeds, and 1.54-1.58 for unrestricted LOST proceeds. This means that the restricted LOST proceeds have a "pooling" equalization effect, but the unrestricted LOST proceeds serve to increase the dispersion of total school capital revenue.

The second panel in the table shows the relative contribution of each revenue source to the Gini index. The contribution is determined not only by Pseudo-Ratios but also by the shares of revenue sources in total revenue. As two dominating driving forces of the inequality, debt proceeds and county general support together accounted for about 98 percent of the dispersion. For debt proceeds, the contributions were about 60 percent in the three-year period; for count general support, around 36-39 percent. The restricted LOST proceeds show only marginal contribution to the overall dispersion, although the 
source accounted for a fairly large portion of total school capital revenue (see Table 2). Unrestricted LOST proceeds and total state aid both have low contributions to the inequality of total school capital revenue.

The third panel in Table 5 presents the marginal effect of a small percentage change in a specific revenue source on the inequality of total capital revenue, holding revenues from all other sources constant. Debt proceeds and county general support are found to have significant impact on raising inequality in capital revenue. A one percent increase in revenue from debt proceeds or county general support, other things being equal, increases the Gini index of total revenue inequality by about 14-16 percent. In contrast, the restricted LOST proceeds have an equalization effect on the distribution of school capital revenue. The negative marginal effects show that a one percent increase in restricted LOST proceeds, holding other things constant, reduces the Gini index by around 27-29 percent. The unrestricted LOST proceeds (as part of county general support) show a positive marginal effect of about 4.5 percent. Combined, the restricted and unrestricted LOST proceeds appear to have an overall equalization effect on the distribution of school capital revenue, given the fact that unrestricted LOST only accounts for a small share of total county general support. State aid also demonstrates a small equalization effect on capital revenue inequality. The marginal effects shown in the table all are statistically significant, as indicated by bootstrapped standard errors. ${ }^{\text {xviii }}$

\section{Equity Effect in Alternative Scenarios of LOST Earmarking and Allocation}

In the final step, we analyze the potential equity effect if the LOST proceeds were earmarked or allocated in alternative ways. Table 6 presents the findings in four different 
scenarios based on data in 2006. Scenario-A represents the status quo: 30 percent of Article 40 LOST and 60 percent of Article 42 LOST are earmarked for school capital outlays, and the proceeds of the two LOST are allocated based on county population. In Scenario-B, the LOST are earmarked at the current ratios, but the proceeds are allocated according to K-12 student numbers in each county. In Scenario-C, we assume that, in order to meet the urgent needs of school capital improvement, $\mathrm{NC}$ changes the current earmarked ratios and fully earmarks the two LOST for school capital outlays, and the proceeds are allocated based on county population. In Scenario-D, the two LOST are fully earmarked with the proceeds allocated based on k-12 student numbers in each county. Note that fully earmarking the two LOST will affect school capital revenues in two ways. On one hand, school districts will get more restricted LOST proceeds; on the other hand, they may receive less indirect LOST proceeds as a part of county general support when counties receive less LOST proceeds (now only from Article 39 LOST and Article 44 LOST). ${ }^{\text {xix }}$

Several observations stand out. First, with the current earmark ratios, allocating proceeds based on student numbers instead of county population will not have a stronger equalizing effect on school capital revenues. In Scenario-B, the overall Gini index (0.39) is actually higher than that (0.37) in Scenario-A, and the size of equalizing marginal effect for restricted LOST proceeds decreases (from -29.1 to -25.7 percent). Second, fully earmarking the two LOST will have a significant equalization effect on school capital revenues. Compared to Scenario-A and -B, Scenario-C and -D have much lower overall Gini indices ( 0.27 and 0.29 , respectively) and much higher amounts of equalizing effects for restricted LOST proceeds (about -44 percent). 
Table 6: Marginal Effects of Capital Revenue Sources in Different Scenarios (2006)

\begin{tabular}{|c|c|c|c|c|}
\hline & Scenario A & Scenario B & Scenario C & Scenario D \\
\hline Gini index of total school capital revenue: & 0.37 & 0.39 & 0.27 & 0.29 \\
\hline \multicolumn{5}{|l|}{$\begin{array}{l}\text { Marginal effects to Gini of school capital } \\
\text { revenues: }\end{array}$} \\
\hline Restricted LOST proceeds & $-29.1 \%$ & $-25.7 \%$ & $-44.2 \%$ & $-44.0 \%$ \\
\hline From LOST-Article 40 & $-9.8 \%$ & $-8.8 \%$ & $-22.1 \%$ & $-22.0 \%$ \\
\hline From LOST-Article 42 & $-18.9 \%$ & $-16.9 \%$ & $-22.1 \%$ & $-22.0 \%$ \\
\hline State aid revenues & $-2.0 \%$ & $-2.0 \%$ & $-0.9 \%$ & $-0.7 \%$ \\
\hline From School Building Capital Fund & $-1.8 \%$ & $-1.8 \%$ & $-0.9 \%$ & $-0.6 \%$ \\
\hline From School Building Bond Fund & $-0.2 \%$ & $-0.2 \%$ & $-0.1 \%$ & $-0.1 \%$ \\
\hline County general support & $15.4 \%$ & $13.9 \%$ & $20.6 \%$ & $19.6 \%$ \\
\hline From property tax & $5.8 \%$ & $5.3 \%$ & $8.0 \%$ & $7.7 \%$ \\
\hline From unrestricted LOST proceeds & $1.6 \%$ & $1.5 \%$ & $1.7 \%$ & $1.6 \%$ \\
\hline From other revenue sources & $7.9 \%$ & $7.2 \%$ & $10.8 \%$ & $10.2 \%$ \\
\hline Debt proceeds for school facilities & $15.7 \%$ & $13.8 \%$ & $24.6 \%$ & $25.1 \%$ \\
\hline Total school capital revenue & $0.0 \%$ & $\mathbf{0 . 0 \%}$ & $0.0 \%$ & $0.0 \%$ \\
\hline
\end{tabular}

Scenario-A: The two LOST (Article 40 and 42) are earmarked and allocated as status quo.

Scenario-B: Earmarked LOST proceeds are allocated by student numbers instead of by population.

Scenario-C: The two LOST (Articles 40 and 42) are fully earmarked and allocated by population.

Scenario-D: The two LOST (Articles 40 and 42) are fully earmarked and allocated by student number.

Finally, when the two LOST are fully earmarked, the allocation of LOST

proceeds (based on county population or numbers of students) makes little difference in revenue equalization. However, as the LOST proceeds become a larger share of school capital revenues, per capita allocation may introduce a new dimension of revenue disparity, when counties with a higher population are not necessarily those with more students.

\section{CONCLUSION}

This study investigates the distribution of public school capital revenues across counties and the relative contribution of various revenue sources to the dispersion of total 
capital revenue for public schools in NC. The partial earmarking of LOST for public school capital outlays also provides us with an interesting case for examining the effects of this specific source of revenue on the equality of spending for school facilities.

The empirical analysis based on a dataset of one hundred counties in NC over the period of 2004-2006 provides evidence that substantial disparities exist in the capacity of counties to raise funding for public school capital outlays. The results from Gini decomposition suggest that municipal bond issuance and county general support were the driving factors of fiscal disparities in public school capital revenues. The restricted LOST proceeds had significant equalizing effect because they were allocated based on county population. Also having equalizing effects were state aid programs. The unrestricted LOST proceeds showed a minor disequalizing effect. With the restricted and unrestricted LOST proceeds combined, they appeared to have an overall equalization effect on the distribution of school capital revenues.

Unlike previous studies indicating that the use of LOST may exacerbate existing disparities in local fiscal capacity due to the positive correlation of local sales tax base and property tax base, this study finds that the adoption and use of several LOST to some extent reduced the inequality in NC counties' capacity for raising funds for school capital projects. The difference lies in the details of institutional arrangements, including how the LOST proceeds are allocated and how they interplay with other revenue sources in the composition of total school capital revenue. Moreover, our analysis with different scenarios of LOST earmarking and allocation sheds additional light on the policy design of LOST. We find that fully earmarking the two LOST (Article 40 and 42) will have a significant equalization effect on school capital revenues. Thus, this can be a feasible 
policy option for the state if $\mathrm{NC}$ attaches a high priority to addressing the issue of fiscal disparities in school capital outlays. We recommend that the state use per-pupil allocation when the amounts of LOST proceeds become substantially larger, and the county population and K-12 enrollment show distinct growth patterns, so as to prevent per-capita allocation of LOST from becoming a new cause of revenue disparity.

This article has several implications concerning the issue of funding disparity for school capital needs, which is worth our special attention in future research. First, in most states, state funding tends to play an important role for improving the equity of education, but the actual impacts vary depending on how the funds are allocated. Given the increasing pressure for states to increase funding for school facilities, it is important to investigate and understand the impact of state capital aid programs with different forms of design.

Second, disparities in education capital funding are more complex than those in education operating expenditures, because both capital revenues and expenditures are less regular or stable. For instance, schools heavily rely on municipal bonds issued only once in several years and use the proceeds raised from the issuance in a period of multiple years. Some schools may spend a high percentage of annual capital outlays on debt services for obligations incurred long before, instead of on current improvements. Consequently, analysis of disparities in school capital outlays on a cross-sectional basis is, by nature, flawed. In this project, we averaged newly issued municipal debt over a nine-year period to measure the level of debt usage, and used other revenues in a threeyear period to assess the trend of capital funding. In future research, we may develop a 
more comprehensive approach to better account for the longitudinal dimension of capital revenues and expenditures, and the intricacy between debt and regular ongoing revenues.

Third, it is worth noting that NC is a special case for the study of school finance. As one of few states in which all school districts are fiscally dependent, NC schools not only receive state grants, but are also dependent on county general fund allocations. This feature makes it a unique case in which to study the equalization effects of LOST proceeds because part of the proceeds is restricted for school capital outlays, but the rest is not. Schools have to compete for unrestricted county general fund allocations against other service needs. On one hand, the study of the unique case of NC may improve our understanding of issues concerning funding for school facilities in fiscally dependent school districts. On the other hand, it will be necessary to conduct further research on independent school districts, to seek additional insights on funding for school facilities in other states.

Lastly, the study shows that the equalizing effect of a revenue source should be examined together with other revenue sources. Previous studies in the area of local fiscal disparity often examined whether a revenue source had an equalization (or disequalization) effect by comparing its distribution to that of other revenues, or by comparing some inequality measures before and after the addition of one other revenue source. Methods of inequality decomposition, such as the standard decomposition of Gini index used in this analysis, move one step further to estimate partial equalization effects for each revenue source. These methods can be more widely used because they may have significant policy implications. 


\section{REFERENCES}

Atkinson, Anthony. (1970). On the measurement of inequality. Journal of Economic Theory, 2(3), 244-63.

Brunner, Eric J., \& Rueben, Kim. (2001). Financing new school construction and modernization: Evidence from California. National Tax Journal, 54(3), 527-539.

Burton, Ramona L. 1999. A study of disparities among school facilities in North Carolina: Effects of race and economic status. Educational Policy, 13(2), 280-295.

Coe, Charles K. (2007). Preventing local government fiscal crises: The North Carolina approach. Public Budgeting \& Finance, 27(3), 39-49.

Crampton, Faith E., David C. Thompson, and Randall S. Vesely (2004). The forgotten side of school finance equity: The role of infrastructure funding in student success. National Association of Secondary School Principals. NASSP Bulletin; 88 (640), 29-52.

Elteto, O and Frigyes, E. (1968). New income inequality measures as efficient tools for causal analysis and planning. Econometrica, 36(2): 383-96.

Fei, J., Ranis, G., \& Kuo, S. (1978). Growth and the family distribution of income by factor components. The Quarterly Journal of Economics, 92(1): 17-53.

Gamkhar, Shama, \& Koerner, Mona. (2002). Inequities in public school capital finance: Evidence from school districts in Texas. National Tax Journal Papers and Proceedings of the 95th Annual Conference on Taxation.

GAO (U.S. Government Accounting Office). (1995). School facilities: States' financial and technical support varies. Washington DC: GAO.

GAO (U.S. Government Accounting Office). (1996). School facilities: Profiles of school condition by state. Washington DC: GAO.

Gerald, Debra E., \& Hussar, William J. (2003). Projections of education statistics to 2013, 32 ${ }^{\text {nd }}$ edition. National Center for Education Statistics, publication 20040-0013.

Gini, Corrado. (1912). Variabilita e mutabilita. Bologna, Cited by Dalton, Hugh (1920). The Measurement of Inequality of Incomes. The Economic Journal, 30, 348-61.

Lawrence, David M., \& Millonzi, Kara A. (2007). Article 13: Revenues. In D. M. Lawrence (Ed.), County and municipal government in North Carolina. Chapel Hill, NC: UNC-Chapel Hill. Available at http://www.sog.unc.edu/pubs/cmg/. 
Lawrence, David M., \& Vogt, A. John. (2007). Article 17: Capital planning, budgeting, and debt financing. In D.M. Lawrence (Ed.), County and municipal government in North Carolina. Chapel Hill, NC: UNC-Chapel Hill. Available at http://www.sog.unc.edu/pubs/cmg/.

Lerman, R., \& Yitzhaki, S. (1985). Income inequality effects by income source: A new approach and applications to the United States. The Review of Economics and Statistics, 67(1), 151-156.

Mesibov, Laurie L., \& Johansen, Ingrid M. (2007). Article 45: Elementary and secondary education. In D. M. Lawrence (Ed.), County and municipal government in North Carolina. Chapel Hill, NC: UNC-Chapel Hill. Available at http://www.sog.unc.edu/pubs/cmg/.

NCES (National Center for Education Statistics, U.S. Department of Education). (2001). Public school finance programs of the U. S. and Canada: 1998-99. Washington, DC: U.S. Department of Education, National Center for Education Statistics. Available at http://nces.ed.gov/edfin/state finance/StateFinancing.asp.

NCDPI (North Carolina Department of Public Instruction). (2003). Procedures manual public school building capital fund. Raleigh, NC: School Planning, Division of School Support.

North Carolina Department of State Treasurer. (2010). State and Local Government Memo Listing. Available at http://www.nctreasurer.com/DSTHome/StateAndLocalGov/AuditingAndReporting/Mem os.htm

Plummer, Elizabeth. (2006). The effects of state funding on property tax rates and school construction. Economics of Education Review. 25(5), 532-542.

Rubenstein, Ross, \& Freeman, Catherine. (2003). Do local sales taxes for education increase inequities? The case of Georgia's ESPLOST. Journal of Education Finance, 28(3), 425-442.

Schutz, R. R. (1951). On the Measurement of Income Inequality. The American Economic Review, 41, 107-22.

SBE (North Carolina State Board of Education). (2005). Public schools of North Carolina: Building on success for superior schools: 2002-2004 biennial report, North Carolina Public Schools.

SBE (North Carolina State Board of Education). (2006). Facility needs survey. 
Sciarra, David G., Bell, Koren L., \& Kenyon, Susan. (2006). Safe and adequate: Using litigation to address inadequate k-12 school facilities. Newark, NJ: Education Law Center.

Sielke, Catherine (2001). Funding school infrastructure needs across the states. Journal of Education Finance, 27(2), 653-662.

Shorrocks, A.F. (1982). Inequality decomposition by factor components. Econometrica, 50(1), 193-211.

Wang, Wen. (2004). Appendix C, A guide to state building aid formulas for elementary and secondary education. In J. Yinger (Ed.), Helping children left behind: State aid and the pursuit of educational equity. Cambridge, MA: MIT Press, 353-366.

Wang, Wen, \& Duncombe, William. (2009). School facilities funding and capital outlay distribution in the states. Journal of Education Finance, 34(3): 324-350.

Zhao, Zhirong, \& Hou, Yilin. (2008). Local option sales taxes and fiscal disparity: The case of Georgia counties. Public Budgeting and Finance, 28(1), 39-57.

Zhao, Zhirong. (2009). Fiscal decentralization and provincial-level fiscal disparities in China: Decomposing the inequality measures. Public Administration Review, 69(s1), S67-S74.

U.S. Census Bureau. (2010). Model-based Small Area Income \& Poverty Estimates (SAIPE) for School Districts, Counties, and States. Available at http://www.census.gov//did/www/saipe/. 


\section{APPENDIX: DECOMPOSITION OF THE GINI INDEX}

According to Fei, Ranis, and Kuo (1978), the Gini index of revenue can be

decomposed by the sources of revenue that make up the total revenue. Let $Y_{i}^{k}$ denote the revenue of individual county $i(i=1, \ldots, n)$ from source $k(k=1, \ldots, K)$, then the Gini index of total revenue, $G(Y)$, can be transformed to

$$
G(Y)=\sum_{k} \frac{\mu_{k}}{\mu} \bar{G}\left(Y^{k}\right)
$$

where $\mu$ is the mean of $Y, \mu_{k}$ is the mean of $Y^{k}$, and

$$
\bar{G}\left(Y^{k}\right)=\frac{2}{n^{2} \mu_{k}} \sum_{i}\left(i-\frac{n+1}{2}\right) Y_{i}^{k}
$$

is known as the pseudo-Gini for source $k$. It is not the conventional Gini value $G\left(Y^{k}\right)$, since the weights attached to $Y_{i}^{k}$ correspond to the rank of individual county $i$ in the distribution of $Y$ which, in general, is not the same as its rank in the distribution of $Y^{k}$. In addition, we can define the absolute and relative contribution of revenue source $k$ to total revenue inequality as $S_{k}(G)$ and $s_{k}(G)$, respectively.

$$
S_{k}(G)=\frac{\mu_{k}}{\mu} \bar{G}\left(Y^{k}\right) ; \quad S_{k}(G)=\frac{S_{k}(G)}{G(Y)}
$$

Equivalently, Lerman and Yitzhaki (1985) show that we can also estimate the effect of a small change $e$ in a specific revenue source $k$ on inequality of total revenue, holding revenue from all other sources constant (See Lerman and Yitzhaki, 1985, p.153).

$$
\frac{\partial G / \partial e_{k}}{G}=s_{k}(G)-\frac{\mu_{k}}{\mu}
$$


${ }^{\mathrm{i}}$ For a more detailed description of the Leandro lawsuit, see

http://www.startingat3.org/_documents/CaseLaw_NC_Hoke.pdf.

ii The Local Government Bond Act of North Carolina limits the amount of net bonded debt that local governments may have outstanding to 8 percent of the assessed value of property subject to taxation.

iii The School Finance Act of 1987 also created the Critical School Facility Needs Fund. The fund was repealed in 1996, and its remaining money was transferred to the Public School Building Capital Fund after 2004 (SBE, 2005).

iv For example, in Leandro v. State, 346 N.C. 336, 357 (1997), the court explained: "Plaintiffs complain of inadequate school facilities... They allege that their poor districts' media centers have sparse and outdated book collections and lack the technology present in the wealthier school districts."

"Like Brunner and Rueben (2001) and many other literature in state and local finance, in this analysis we assume that higher property values are associated with higher tax capacity for local governments. Note that, at the individual level, property tax base is not necessarily connected to the ability to pay, because taste for housing can be idiosyncratic. Some low to middle income families might be attracted to "better" schools (with higher per pupil capital revenues) and be willing to pay a higher percentage of their incomes for housing.

${ }^{\mathrm{vi}}$ Surprisingly, he finds that the condition of school facilities improves modestly as the share of African American students goes up.

vii One major difference between the two approaches is whether or not they account for the possibility of a local government to export tax burdens to nonresidents of the jurisdiction.

viii All financial data used for this analysis are adjusted for inflation.

${ }^{i x}$ There are many different ways to measure inequality in the context of school capital financing. The Gini index is used frequently because it is closely related to the Lorenz curve of an income distribution and has a simple geometric interpretation, but it has some disadvantages too, such as its relative insensitivity to transfers for non-middle income classes (Elteto and Frigyes, 1968). For example, a variety of distribution of the measure of income (or revenue capacity) can yield the same Gini (Schutz, 1951). Nevertheless, other inequality measures have their disadvantages too as they attach different weight to transfers at different income levels (Atkinson, 1969). We shall also note that, in this analysis, the inequality is assessed at the county level in terms of local fiscal capacity. It is not necessarily connected with individual's ability to pay (see endnote $\mathrm{v}$ ).

${ }^{x}$ The distribution of capital revenue appears to be similar in 2004-2006.

${ }^{x i}$ We used other revenues in a three-year period rather than a nine-year period because of the change in state aid programs. We could not obtain the revenue data for the Critical School Facility Needs Fund before the merger of the fund into the Public School Building Capital Fund in 2004.

${ }^{x i i}$ Property tax, unrestricted LOST, and other revenues in county general support for school capital outlays are estimated based on the share of these revenue sources in total county general revenue. Some counties also have a special property tax levy to pay back general obligation municipal bonds. The data are not included in the county general support.

xiii The use of restricted LOST proceeds to partly cover debt service payments can help preserve counties' debt capacity to be supported by their property tax base.

${ }^{\text {xiv }}$ Families in poverty refer to families whose 1999 income falls below the poverty threshold appropriate to that family in the Census 2000 record. For the definition and methodology, please see

http://www.census.gov/did/www/saipe/methods/schools/data/2005.html.

${ }^{\mathrm{xv}}$ Another criterion for the School Building Capital Fund's allocation is student enrollment, but we do not observe any significant pattern of enrollment or enrollment growth across county quartiles in Table 4.

${ }^{x v i}$ The use of Gini index to measure revenue inequality in this article does not control for factors that may affect school capital needs such as student enrollment growth. Thus we report our findings as "capital revenue disparities" instead of "capital fiscal disparities," which ideally should be measured based on the need-capacity gap of school districts in providing facilities.

xvii To include both debt proceeds and LOST revenues may be double-counting to some extent, because part of the LOST revenues is used to repay the debt. Ideally, we should subtract the proceeds of municipal debts that are paid back by earmarked LOST revenues, but the data are not available. 
xviii The results of bootstrapped standard errors are not included in the table, but are available from authors by request.

${ }^{x i x}$ The unrestricted LOST proceeds for school capital outlays are estimated based on the assumption that counties allocate a certain percentage of their total general fund revenue (regardless of revenue sources including property tax, LOST, or others) for school capital outlays. Therefore, if a county's un-earmarked LOST proceeds decrease by a percentage, the unrestricted LOST proceeds allocated for school capital outlays will decrease at the same percentage. 